\title{
Age Effects on the Process of L2 Acquisition? Evidence From the Acquisition of Negation and Finiteness in L2 German
}

\author{
Christine Dimroth \\ Max-Planck-Institut für Psycholinguistik
}

It is widely assumed that ultimate attainment in adult second language (L2) learners often differs quite radically from ultimate attainment in child L2 learners. This article addresses the question of whether learners at different ages also show qualitative differences in the process of L2 acquisition. Longitudinal production data from two untutored Russian beginners (ages 8 and 14) acquiring German under roughly similar conditions are compared to published results on the acquisition of German by adult immigrants. The study focuses on the acquisition of negation and finiteness as core domains of German sentence grammar. Adult learners have been shown to produce an early nonfinite learner variety in which utterance organization relies on principles of information structure rather than on target language grammar. They then go through a couple of intermediate steps in which, first, semantically empty verbs (auxiliaries) serve as isolated carriers of finiteness before lexical verbs become finite. Whereas the 14-year-old learner of this case study basically shows a developmental pattern similar to that of adults, the 8-year-old child produces a different order of acquisition: Not only is the development of finite morphology faster, but finite lexical verbs are acquired before auxiliary constructions (Perfekt). Results suggest a stronger tendency for young learners to incrementally assimilate input patterns without relying on analytic steps guided by principles of information organization to the same extent as older learners.

Keywords untutored L2 acquisition; age factor; child L2 learners; orders of acquisition; finiteness; negation; longitudinal production study

\footnotetext{
I am most grateful to David Birdsong, Kathrin Kirsch, Wolfgang Klein, Leah Roberts, and Roman Skiba, as well as two anonymous reviewers, who made helpful comments on earlier versions of this article, which was first presented at the colloquium "Attaining the Ultimate: An Expert Meeting on the Occasion of Theo Bongaerts' Retirement," Nijmegen 2004.

Correspondence concerning this article should be addressed to Christine Dimroth, MaxPlanck-Institut für Psycholinguistik, PB 310, 6500 AH Nijmegen, The Netherlands. Internet: christine.dimroth@mpi.nl
} 
Even though some recent findings shed doubts on the principled limitations of adult second language (L2) learners (e.g., Birdsong, 2004; Bongaerts, 1999; Van Boxtel, Bongaerts, \& Coppen, 2003), most researchers would probably maintain that the slogan "the younger the better" is a valid generalization on the relation between age of onset and ultimate attainment in untutored second language acquisition (SLA; e.g., DeKeyser, \& Larson-Hall, 2005; Hyltenstam, \& Abrahamson, 2003; Singleton \& Ryan, 2004). Studies on the age factor in SLA thereby take it that only end-state data can further inform us about the impact of a learner's age at the beginning of the L2 acquisition process. Developmental data, interesting as they might be, "do not directly speak to the potential of the learner, which is an inescapable consideration of L2A [second language acquisition] theory" Birdsong (p. 82). Some researchers even take it for granted that there are no telling differences in the learning process as such: "Cognitive explanations would predict fundamentally different learning processes for children and adults (in terms of order and sequence of acquisition etc.), which does not seem to be the case" (Hyltenstam \& Abrahamson, p. 566); or "Results of research into various dimensions of the way in which L2 learning proceeds suggest that age differences between adults and children are of little significance as far as the L2 acquisition process is concerned" (Singleton \& Ryan, p. 115).

Others formulate some concerns with regard to the evidence on which these claims are based: "Regarding the route of acquisition, the age factor does not seem to have much effect. [...] Because of a lack of carefully designed longitudinal studies, the effect of age on the route of L2 acquisition is inconclusive at this point" (Butler \& Hakuta, 2004, p. 126).

This article aims to address the question of whether children's early L2 development is really similar to what has been observed in older subjects. To this aim, longitudinal production data from untutored L2 learners of German at three different ages were investigated. Spontaneous speech data from a longitudinal case study involving a child and an adolescent learner will be compared to published findings on the developmental path of adult learners. I will focus on the very beginning of the acquisition process.

The study concerns the acquisition of negation and finiteness (i.e., the formal marking of finite verbs [inflection, position] and its function in a clause). This domain has been selected for the following reasons:

1. It is a broad acquisitional task involving semantic, syntactic, and morphological knowledge.

2. It is crucial for the structure of learner utterances from the very beginning. 
3. There is sufficiently clear and conclusive evidence about orders of acquisition in untutored adults.

4. There is an important theoretical discussion concerning the relation between finiteness and negation in language acquisition (see below for a summary).

In the next section, I will briefly explain how negation and finiteness are expressed in German and Russian, the source language of the learners. Then I will summarize published findings on orders of acquisition attested in adult learners of L2 German. Following this, I will present the results of a longitudinal case study on the acquisition of German by an adolescent and a child learner and summarize similarities and differences. The last section discusses the findings in relation to the age factor in SLA.

\section{Negation in Source and Target Languages}

This study is mainly concerned with sentence negation. ${ }^{1}$ The negator is assumed to be a semantic operator that has scope over the predicate part of an utterance and expresses that the application of the given predicate to the topic of the sentence does not yield a true sentence.

\section{German}

The general rule for sentence negation in German is that the negator nicht precedes the nonfinite verb(s) (or the predicative complement). German is a V2 language: Thus, in declarative main clauses (1) the finite verb occurs in second position and the nonfinite verb is in clause-final position; in subordinate clauses (2), both the finite and the nonfinite verb occur clause-finally. In both kinds of clause, the position of the negator nicht (not) is in front of the nonfinite verb:

(1) Heute hat er nicht gearbeitet

Today has he not worked

"He hasn't worked today"

(2) ...dass er heute nicht gearbeitet hat

...that he today not worked has

"...that he hasn't worked today"

In predicative constructions, nicht appears to the left of the predicative complement:

(3) Die Äpfel sind nicht billig

The apples are not cheap 
When the sentence does not contain an auxiliary verb, the finite lexical verb occurs in the V2 position, whereas the negator stays in its original position, which can then also be clause-final as in (4):

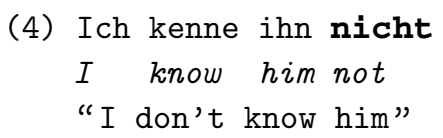

Furthermore, the German sentence negator nicht typically precedes all prepositional phrases and other adverbials. If negation precedes an indefinite NP, nicht is often replaced by the "cohesive" negator kein:

(5) Sie hat keine Meinung

She has not-a opinion

"She doesn't have an opinion"

\section{Russian}

In Russian, the negator is placed in the immediate pre-finite position, independently of the nature of the finite verb. The unmarked word order is SVO, but the subject is frequently left implicit if reference can be recovered from the context. In this case, the negator can even show up in first position:

(6) (Jan) ne poexal v Moskvu

(Jan) not went to Moscow

"Jan didn't go to Moscow"

(7) (Jan) ne xochet exat' v Moskvu

(Jan) not wants to go to Moscow

"Jan doesn't want to go to Moscow"

Because there is no overt copula in attributive constructions in the present tense, the negator occurs between the subject and the predicative complement, whereas it is again in prefinite position in past tense copula constructions:

(8) Jan ne bol'shoj

Jan not tall

"Jan isn't tall"

Jan ne byl bol'shim

Jan not was tall

"Jan wasn't tall"

When existential constructions are negated, the negative particle net [historically $=$ "ne +est" (not + is $)]$ is used: 
(9) V Moskve net gollandskoj biblioteki

In Moscow not Dutch library-GEN

"There is no Dutch library in Moscow"

The main difference between the two languages is that the German sentence negator always appears in a position after the finite verb, whereas it directly precedes the finite verb in Russian.

\section{Negation and Finiteness in L2 German by Adult Immigrants: Three Stages}

From very early on, the acquisition of negation in L2 German (and other target language ${ }^{2}$ ) has been studied in relation to the verb. With respect to L2 German, we find contradictory claims about the relation between negation and finiteness (e.g., Dietrich \& Grommes, 1998; Meisel, 1997; Parodi, 2000). This has mainly to do with different interpretations of the notion of finiteness. Depending on whether studies take finiteness to refer to the morphological marking of subjectverb agreement, or to the position of the finite verb in a sentence (raised to V2, above negation), or to semantic properties (e.g., sassertion; see Klein, 2006), they come to different conclusions regarding its acquisition.

In this article, we are mainly concerned with negation and verb raising and its relation to the expression of semantically finite assertions. In this context, nonthematic verbs, which mainly serve as lexically empty carriers of features of finiteness, have been found to play a particularly important role (Parodi, 2000). Focusing on studies that have taken the special role of nonthematic verbs (auxiliaries in particular) into account, we can subsume the main findings for untutored adult learners of L2 German (see Becker, 2005; Giuliano, 2003; Jordens Dimroth, 2006; Parodi, 2000) in the following unified scheme (Table 1).

The crucial role of Step 2 in the reorganization of the learner grammar has to do with the idea that auxiliary verbs in particular help the learner to

Table 1 Orders of acquisition in untutored adult learners of L2 German

I Lexical verbs (tentatively marked for morphological finiteness or not) appear to the right of the negator. Early modals and the copula can show up in finite form and position (i.e., to the left of the negator).

II The perfect is acquired. Auxiliaries appear (as do other nonthematic verbs) in finite form and position (i.e., to the left of the negator).

III Lexical verbs occur with postverbal negation. The acquisition of target adequate morphological marking of finiteness continues. 
establish both a relation of morphological agreement between the auxiliary and the external argument, and a head-complement relation between the auxiliary and the lexical verb. At the same time, they allow the learner to maintain a separate encoding for finiteness and the lexical content of verbs. This also means that the scope of negation can still be marked in a transparent way, as all elements (including the lexical verb) that are in the scope of the negator in normal sentence negation occur to its right. These advantages seem to determine the order of acquisition of finiteness in adult learners of German or Dutch: The acquisition of the perfect is a necessary intermediate step before morphosyntactic finiteness marking becomes productive with lexical verbs.

In Step 3, when finite lexical verbs with postverbal negation come to be used, the transparent separation of finite and nonfinite forms is given up in favor of the fusion of functional and lexical information. Learner utterances then have a syntactic structure in which scope and information structure can no longer be directly mapped onto surface order. Other finiteness-related properties, like the $\mathrm{V} 2$ rule, the final position of finite verbs in subordinate clauses, or subject-verb agreement, are acquired independently (Becker, 2005).

The point in development at which the perfect is acquired can easily be identified in longitudinal data. In the following, we will therefore use this step as a point of comparison for the development of negation and finiteness in learners at different ages. The following section presents results concerning the presence and order of these three stages in the longitudinal production data of an adolescent learner (age 14; 2 ) and a child learner (age 8; 7) of L2 German. ${ }^{3}$

\section{Negation and Finiteness in L2 German by an Adolescent and a Child Learner}

The data analyzed in the following subsections were collected under the direction of U. Stephany (Köln University) and transcribed, coded, and partly analyzed in the DFG project DaZ-AF (C. Dimroth, MPI Nijmegen, and U. Stephany, Köln University; see Bast [2003] for a detailed description of the project and database).

\section{Participants}

The two learners included in this longitudinal case study are sisters who came from St. Petersburg to Cologne, where they stayed for 1.5 years. Except for $8 \mathrm{hr}$ of teaching before departure from St. Petersburg, neither of the participants had any contact with German. 
Upon arrival in Germany, the child learner Nastja was 8;7 and the adolescent learner Dascha was 14;2 years old. They lived with their Russian-speaking mother, a visiting professor at the University of Cologne, and the family language continued to be Russian. Nastja attended the second grade of a German primary school ("Grundschule") and Dascha attended the ninth grade of a German comprehensive secondary school ("Gymnasium”). Nastja had no prior contact with languages other than Russian, whereas Dascha had learned English for 6 years in her school in Russia. Instruction (5-6 hr weekly) in a very formal setting started when she was 8 years old and continued in her new school in Germany. According to her mother, Dascha could read, write, and translate, but she was barely able to conduct a free conversation in English. We cannot exclude the possibility that her experience with learning another foreign language might have had a general effect on her metalinguistic awareness or a more specific effect on the way in which she approached the task of learning German. We will come back to possible influences of Dascha's knowledge of English in the Results section.

\section{Data}

The subjects' oral speech production was audio-recorded on a weekly basis (for approximately $1 \mathrm{hr}$ a week), mainly in free conversation with adult or age-matched native interlocutors. Recordings started in the third week of the sisters' residence in Germany. With respect to negation and finiteness as defined earlier, there is no difference between the learners at the end of the observation period (after 18 months of target language contact). Both learners produce only utterances with targetlike tense and agreement marking and postfinite negation. The differences in finiteness marking cease so early that only data from the first 23 weeks of residence are included in the present analysis (week 3 to week 25). This corresponds to an uninterrupted stay from arrival in January up to the beginning of the summer vacation that both sisters spent in Russia. Week 14 was the only one in which no recording was made (see Table 2). During these first months of the girls' stay in Germany, the amount of target language input was comparable. In some weeks, two short recordings were made instead of one longer one. As a result, there is no one-to-one correspondence between number of recording and week of residence. For ease of comparison, results are presented with reference to the weeks of residence. Recording numbers are given in parentheses. In the indications following the examples only the recording numbers referring to the corpus are used.

The recordings made with age-matched interlocutors especially consist of less structured, but very natural conversation occurring while playing games 
Table 2 Dates and lengths of recordings

\begin{tabular}{|c|c|c|c|c|c|c|c|c|}
\hline \multirow[b]{2}{*}{ Weeks } & \multicolumn{4}{|c|}{ Recordings Dascha } & \multicolumn{4}{|c|}{ Recordings Nastja } \\
\hline & No. & Dates & $\begin{array}{l}\text { Length } \\
\text { (min) }\end{array}$ & $\begin{array}{c}\text { No. of } \\
\text { D.'s words }\end{array}$ & No. & Dates & $\begin{array}{l}\text { Length } \\
\text { (min) }\end{array}$ & $\begin{array}{c}\text { No. of } \\
\text { N.'s words }\end{array}$ \\
\hline 3 & 01 & $23-01-98$ & 50 & 722 & 01 & $22-01-98$ & 61 & 892 \\
\hline \multirow[t]{2}{*}{4} & 02 & $28-01-98$ & 43 & 507 & 02 & $28-01-98$ & 43 & 141 \\
\hline & 03 & $29-01-98$ & 42 & 785 & 03 & $29-01-98$ & 41 & 235 \\
\hline 5 & 04 & $05-02-98$ & 55 & 2,260 & 04 & $05-02-98$ & 53 & 90 \\
\hline 6 & 05 & $12-02-98$ & 60 & 1,250 & 05 & $12-02-98$ & 60 & 327 \\
\hline 7 & 06 & $19-02-98$ & 55 & 824 & 06 & $19-02-98$ & 37 & 365 \\
\hline 8 & 07 & $27-02-98$ & 65 & 1,299 & 07 & $27-02-98$ & 61 & 1,053 \\
\hline 9 & 08 & $05-03-98$ & 60 & 756 & 08 & $05-03-98$ & 60 & 2,080 \\
\hline 10 & 09 & $12-03-98$ & 62 & 1,405 & 09 & $13-03-98$ & 65 & 1,509 \\
\hline \multirow[t]{2}{*}{11} & 10 & $21-03-98$ & 30 & 873 & 10 & $21-03-98$ & 65 & 1,731 \\
\hline & 11 & $23-03-98$ & 31 & 612 & & & & \\
\hline 12 & 12 & $26-03-98$ & 56 & 633 & 11 & $26-03-98$ & 65 & 1,631 \\
\hline 13 & 13 & $02-04-98$ & 60 & 1,169 & 12 & $02-04-98$ & 60 & 2,097 \\
\hline \multicolumn{9}{|l|}{14} \\
\hline 15 & 14 & $17-04-98$ & 65 & 1,998 & 13 & $17-04-98$ & 65 & 3,438 \\
\hline 16 & 15 & $25-04-98$ & 64 & 1,612 & 14 & $25-04-98$ & 64 & 1,676 \\
\hline 17 & 16 & $30-04-98$ & 52 & 1,363 & 15 & 29-04-98 & 57 & 1,487 \\
\hline 18 & 17 & $08-05-98$ & 65 & 2,644 & 16 & 08-05-98 & 48 & 1,573 \\
\hline 19 & 18 & $14-05-98$ & 65 & 1,610 & 17 & $14-05-98$ & 65 & 2,293 \\
\hline 20 & 19 & $20-05-98$ & 65 & 1,077 & 18 & $20-05-98$ & 48 & 1,303 \\
\hline 21 & 20 & $28-05-98$ & 63 & 2,165 & 19 & $28-05-98$ & 65 & 4,981 \\
\hline 22 & 21 & 04-06-98 & 63 & 2,090 & 20 & 04-06-98 & 63 & 3,046 \\
\hline 23 & 22 & $16-06-98$ & 56 & 1,148 & 21 & $10-06-98$ & 65 & 1,165 \\
\hline 24 & 23 & $18-06-98$ & 65 & 2,602 & 22 & $19-06-98$ & 65 & 3,501 \\
\hline 25 & 24 & $22-06-98$ & 65 & 2,259 & 23 & $22-06-98$ & 65 & 3,728 \\
\hline
\end{tabular}

or looking at photos, books, or catalogs. These different types of activities account for the huge variation in the numbers of word tokens produced by the subjects, which also affects the total amount of negative utterances that could be analyzed; sometimes contexts for more complete negative utterances were just absent and anaphoric negation prevailed. This is especially the case for Nastja's recordings $02-04$, which contain only a very small number of self-initiated and relatively "complete" learner utterances. These recordings were made with a child interlocutor (8-year-olds like Nastja) and it was later found that both children were mostly playing silently or making some highly context-dependent 
and elliptic comments on the situation instead of talking to each other in a more context-independent way.

The audio-recordings were transcribed in the CHAT format by a native speaker of German and double-checked by another native speaker. Transcripts were coded for selected morphosyntactic properties and analyzed using the CLAN tools (MacWhinney, 2000).

\section{Results}

The following two subsections deal with the findings for the adolescent learner Dascha and the child learner Nastja, respectively. A comparison of the main results is provided subsequently.

\section{Acquisition of Negation and Finiteness in the Adolescent Learner Dascha} In this subsection I will first consider finiteness marking in nonnegated utterances, therefore merely presenting a rough sketch of the development of word order, the presence and form of nonthematic verbs, tense marking, and subjectverb agreement with lexical verbs. The relation of finiteness and negation will be analyzed in the subsection thereafter.

\section{Finiteness in Nonnegated Utterances}

The adolescent learner uses lexical verbs and the copula from the first recording onwards (third week of residence in the target language environment). Modal verbs appear only 2 weeks later. The first unambiguous instance of the perfect appears in week 15 (three tokens of one fixed auxiliary-past participle combination) and becomes more productive and frequent from week 17 onward. This is of particular importance for the further argumentation because the acquisition of other finiteness-related properties is going to be discussed in relation to the time at which the perfect and therewith finite nonmodal auxiliaries are acquired. Table 3 displays the order of acquisition of different verb types and analytic constructions (types/tokens).

Early usage and further development of these verb types will be illustrated by a few examples. Numbers in parentheses following the learner utterances indicate the number of the recording from which the example is taken. An example labeled D-01 stems from Dascha's first recording, which took place in her third week of residence in Germany (see Table 2). As can be seen in (10a), the copula in the third person singular is already used in a target adequate way in the first recording. Constructions with a missing copula (10b) are rare and disappear quickly. The copula starts to be consistently marked for subject-verb agreement in D-03 (i.e., after 4 weeks of residence; [10]-[10d-e] as opposed to [10]). 
Table 3 Order of acquisition of different verb types in the adolescent learner Dascha

\begin{tabular}{lllll}
\hline Week (No.) & Vlex & Cop $^{\mathrm{a}}$ & Mod & Aux $^{\mathrm{b}}$ \\
\hline $3(01)$ & $4 / 9$ & 19 & & \\
$4(02+03)$ & $4 / 5$ & 49 & & \\
$5(04)$ & $8 / 18$ & $\ldots$ & $3 / 4$ & \\
$6(05)$ & $4 / 4$ & $\ldots$ & $3 / 3$ & \\
$7(06)$ & $7 / 7$ & $\ldots$ & $3 / 7$ & \\
$8(07)$ & $7 / 11$ & $\ldots$ & $5 / 8$ & \\
$9(08)$ & $6 / 8$ & $\ldots$ & $\ldots$ & \\
$10(09)$ & $\ldots$ & $\ldots$ & $\ldots$ & \\
$11(10+11)$ & $\ldots$ & $\ldots$ & $\ldots$ & \\
$12(12)$ & $\ldots$ & $\ldots$ & $\ldots$ & $5 / 3$ \\
$13(13)$ & $\ldots$ & $\ldots$ & $\ldots$ & \\
$15(14)$ & $\ldots$ & $\ldots$ & $\ldots$ & $6 / 16$ \\
$16(15)$ & $\ldots$ & $\ldots$ & $\ldots$ & $6 / 12$ \\
$17(16)$ & $\ldots$ & $\ldots$ & $\ldots$ & \\
$18(17)$ & $\ldots$ & $\ldots$ & $\ldots$ & \\
$19(18)$ & $\ldots$ & $\ldots$ & $\ldots$ & \\
$20(19)$ & $\ldots$ & $\ldots$ & $\ldots$ & \\
$21(20)$ & $\ldots$ & $\ldots$ & $\ldots$ & \\
$22(21)$ & $\ldots$ & $\ldots$ & $\ldots$ & \\
$23(22)$ & $\ldots$ & $\ldots$ & $\ldots$ & \\
$24(23)$ & $\ldots$ & $\ldots$ & $\ldots$ & \\
$25(24)$ & $\ldots$ & $\ldots$ & $\ldots$ & \\
\hline
\end{tabular}

${ }^{a}$ All forms of the copula were counted as one (lexical) type.

${ }^{\mathrm{b}}$ To make sure that the learner does not only use fixed collocations, type indications here refer to occurrences of auxiliaries with different past participles.

(10) Early occurrences of the copula
a. fünf das
ist
sehr gut (D-01)
five that
is
very good
b. frau $\mathrm{H}$.
lehrerin (D-02)
Mrs. $H$.
teacher
c. die blümen
ist
rosa (D-02)
the flowers
pink
d. ich
I
e. sie
they
is
gut in englisch (D-03)
good in English
am
sind
böse (D-04)
are
angry 
Dascha initially produces utterances with an SVO word order, which is the default word order in the learner's first language (L1; Russian) ${ }^{4}$ and her first foreign language (English). Many German input sentences have an SVO surface order, too. When the first modal constructions are used, the learner has not yet acquired the correct morphosyntactic marking for the lexical verbs (end position with infinitival ending). Modal verb and lexical verb first appear in adjacent position. The form of the lexical verb is often taken from the target language's repertoire of finite forms (11)-(11a-b). Later, both verbal parts become separated $[(11 \mathrm{c})]$ :

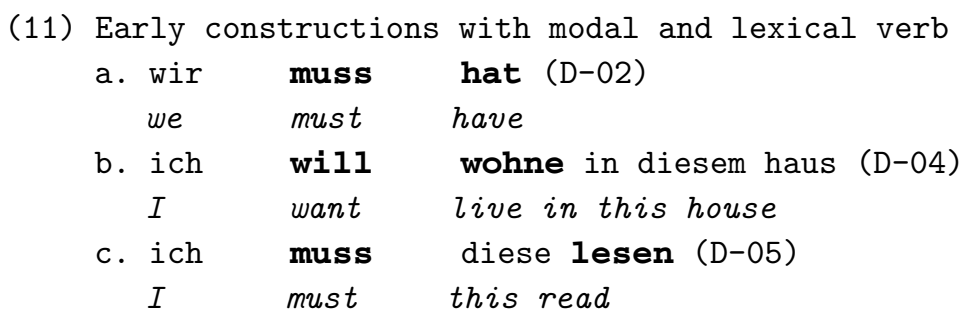

Some of the very first instances of the perfect show the same verbal cluster as the early modal constructions (12a). These difficulties with the targetlike position for the nonfinite part of the verb (the past participle) seem to be due to the SVO word order that the learner first assumes. The default auxiliary is haben (12b), it is also used in contexts in which the target language uses sein [(12c)]. During the first 6 months, sein only occurs with the adjectivelike past participle geschrieben, "written" [see (12d)].

(12) First occurrences of the perfect:

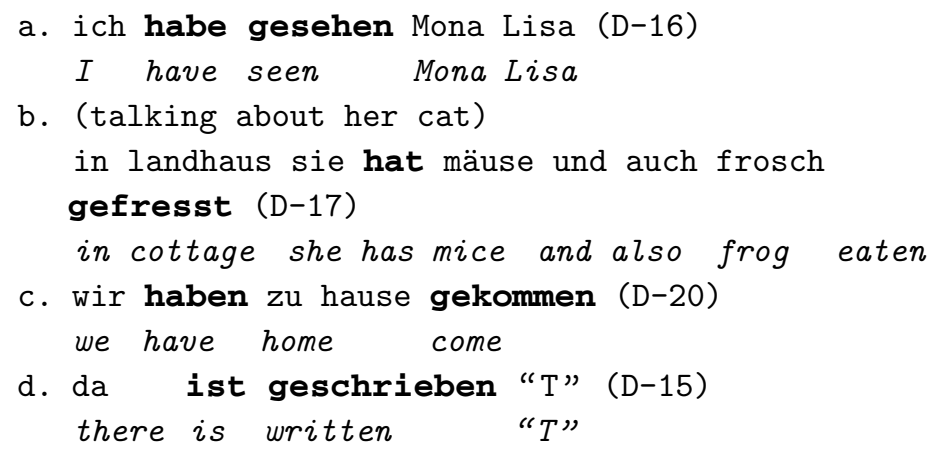

We now turn to an analysis of subject-verb agreement and tense marking on lexical and nonthematic verbs. Table 4 shows the development of these 
Table 4 Acquisition of verbal inflections in the adolescent learner Dascha

\begin{tabular}{|c|c|c|c|c|c|}
\hline \multirow[b]{2}{*}{ Week (No.) } & \multirow{2}{*}{$\begin{array}{c}\text { Subj.-verb } \\
\text { agreement (Vlex) }\end{array}$} & \multicolumn{3}{|c|}{ Past tense } & \multirow{2}{*}{$\begin{array}{c}\text { Aux }^{\mathrm{a}} \\
\text { (perfect) }\end{array}$} \\
\hline & & Cop & Mod & Vlex & \\
\hline \multicolumn{6}{|l|}{$3(01)$} \\
\hline \multicolumn{6}{|l|}{$4(02+03)$} \\
\hline $5(04)$ & $-\mathrm{e}(1 . \mathrm{sg})$ vs. $-\mathrm{t}(3 . \mathrm{sg})$ & 1 & & & \\
\hline $6(05)$ & - st $(2 . s g)$ & & & & \\
\hline $7(06)$ & & 1 & & & \\
\hline $8(07)$ & -en (1.pl) & 2 & & 1 & \\
\hline $9(08)$ & & 1 & & & \\
\hline \multicolumn{6}{|l|}{$10(09)$} \\
\hline $11(10+11)$ & & 1 & & $1 / 2$ & \\
\hline \multicolumn{6}{|l|}{$12(12)$} \\
\hline $13(13)$ & & 4 & & 1 & \\
\hline $15(14)$ & & 12 & & 1 & $1 / 3$ \\
\hline $16(15)$ & & 1 & 1 & & \\
\hline $17(16)$ & & 20 & & $4 / 4$ & $5 / 8$ \\
\hline $18(17)$ & -en (3.pl) & 23 & $1 / 2$ & 1 & $9 / 16$ \\
\hline $19(18)$ & & 15 & $2 / 5$ & 1 & $6 / 12$ \\
\hline $20(19)$ & & 1 & & & $2 / 3$ \\
\hline $21(20)$ & & 11 & 1 & $2 / 3$ & $10 / 23$ \\
\hline $22(21)$ & & 9 & $2 / 2$ & 1 & $8 / 21$ \\
\hline $23(22)$ & & 15 & $1 / 2$ & 1 & $6 / 10$ \\
\hline $24(23)$ & & 12 & $2 / 7$ & $2 / 3$ & $18 / 48$ \\
\hline $25(24)$ & & 7 & $1 / 10$ & & $5 / 11$ \\
\hline
\end{tabular}

${ }^{\text {a }}$ Type indications here refer to occurrences of auxiliaries with different past participles.

properties over time. A column with the first occurrences of the perfect (from Table 3) is added and the rows displaying the data from the recordings in which the perfect is first used productively are shaded for ease of comparison.

Agreement of lexical verbs is acquired gradually from the fifth week onward. An analysis of productivity conducted in terms of proto-morphology (Bittner, 2003) was carried out in order to show how the agreement paradigm unfolds. A suffix only counts as acquired when it is used with at least three different verb lemmas in the correct context and the given context is not marked more frequently (tokens) with some other suffix..$^{5}$

In Dascha's data, first and third person singular are morphologically distinguished from the fifth week of residence onward, but, at the same time, the inflectional endings for both of these are the ones that are most frequently 
overextended to other persons. The overextension of $-e$ is mainly due to the use of the form habe for the first person plural:

(13) Overextensions of the $-e$ suffix

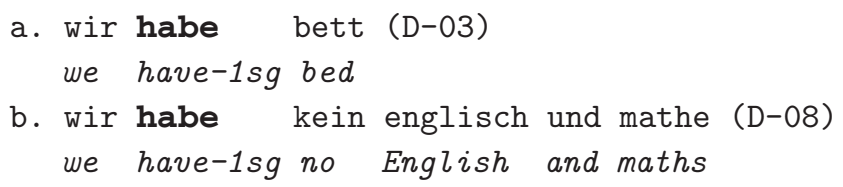

In the case of $-t$, this is mostly due to a confusion of this person marking suffix with the past tense marker. The next suffixes to reach the criteria for productive use are $-s t$ in second person singular contexts in week 6 and -en in first person plural contexts in week 8 , which is much earlier than the acquisition of the perfect (weeks 15-17). This is a clear difference from the findings from studies of adult learners, for which it has been claimed that the correctness of agreement marking increases only after the acquisition of auxiliary verbs.

Past tense is marked on the copula first (productively used from week 13 onward). Lexical verbs that are marked for past tense and occur in past tense contexts remain rare and unstable throughout the first 6 months of recordings. Before week 17, the past tense of lexical verbs cannot be said to be used productively (four out of five earlier occurrences are the forms wusste or stand, both irregular forms of strong verbs that can only be rote learned). The first regular form is wohnte in week 15 . The first occurrences of modal verbs in the past tense are in week 18. These first tense contrasts appear around the same time as the acquisition of the perfect, which first occurs in week 15 and becomes productive from week 17 onward. Examples for the development of past tense in the different verb types (copula [(14a)], lexical verbs [(14b-c)], modal verbs $[(14 d)])$ are given below.

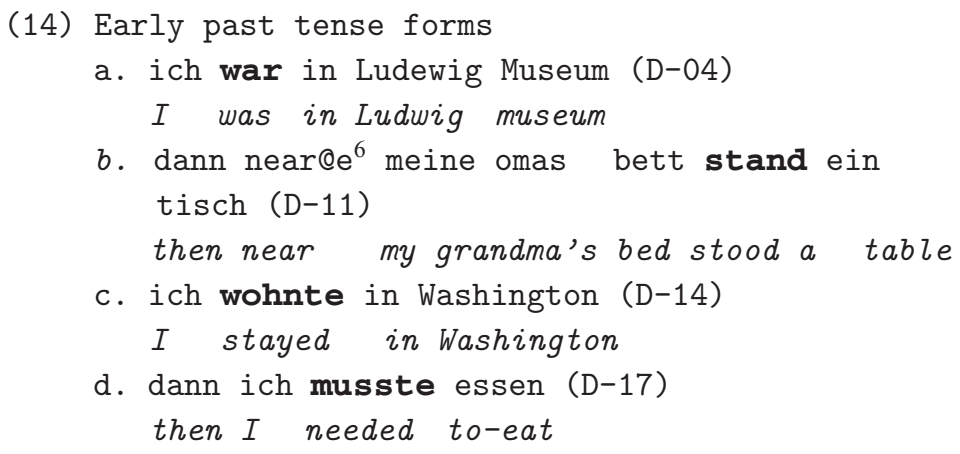


The point at which the perfect first comes to be used productively (between week 15 and week 17, marked in light gray in Table 4) correlates with the acquisition of past tense marking. This step is thus comparable to Step 2 in the acquisition order attested for adults (compare Table 1). It will have to be shown whether Step 3 (postverbal negation with lexical verbs) occurs only after this turning point in the adolescent learner, too.

\section{Negation Before and After the Acquisition of the Perfect}

The development of negative placement with thematic and nonthematic verbs in relation to the acquisition of finiteness in nonnegated utterances is summarized in Table 5. The gray area marks the acquisition of finite auxiliaries in nonnegated perfect constructions. We will now analyze the development of negation with nonthematic and lexical verbs and thereby focus on the question if the acquisition of finiteness co-occurs with changes in the structure of negated utterances.

Let us first turn to negation of nonthematic verbs. In the very beginning (up to and including week 8) we attest a few negative clauses in which a copula is missing. The disappearance of this phenomenon in the learner Dascha is not related in time to the acquisition of the perfect.

(15) Negative utterances lacking a copula

a. das nicht auto (D-04)

this not car

b. das nicht englisch (D-07)

this not English

Utterances that contain a copula and a negator are attested much more frequently and also appear from the very beginning onwards. The position of nicht is always to the right of the copula. There are no great changes with respect to this structure over time, but the copula itself becomes marked for person/number and tense. This, again, is not related to the acquisition of the perfect occurring around weeks 15-17.

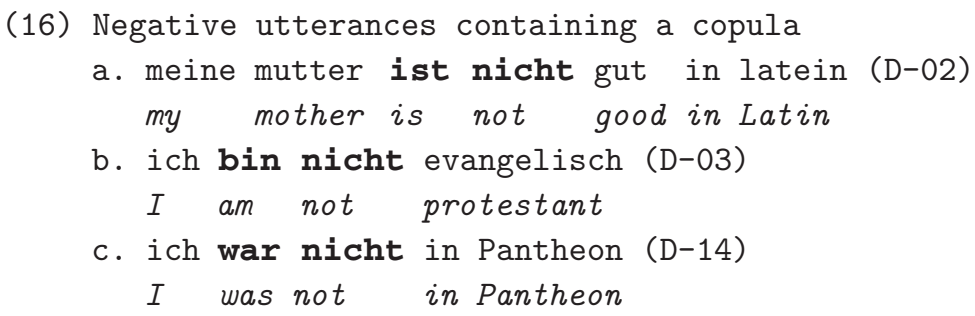


Table 5 Negative placement in relation to the acquisition of the perfect in the adolescent learner Dascha

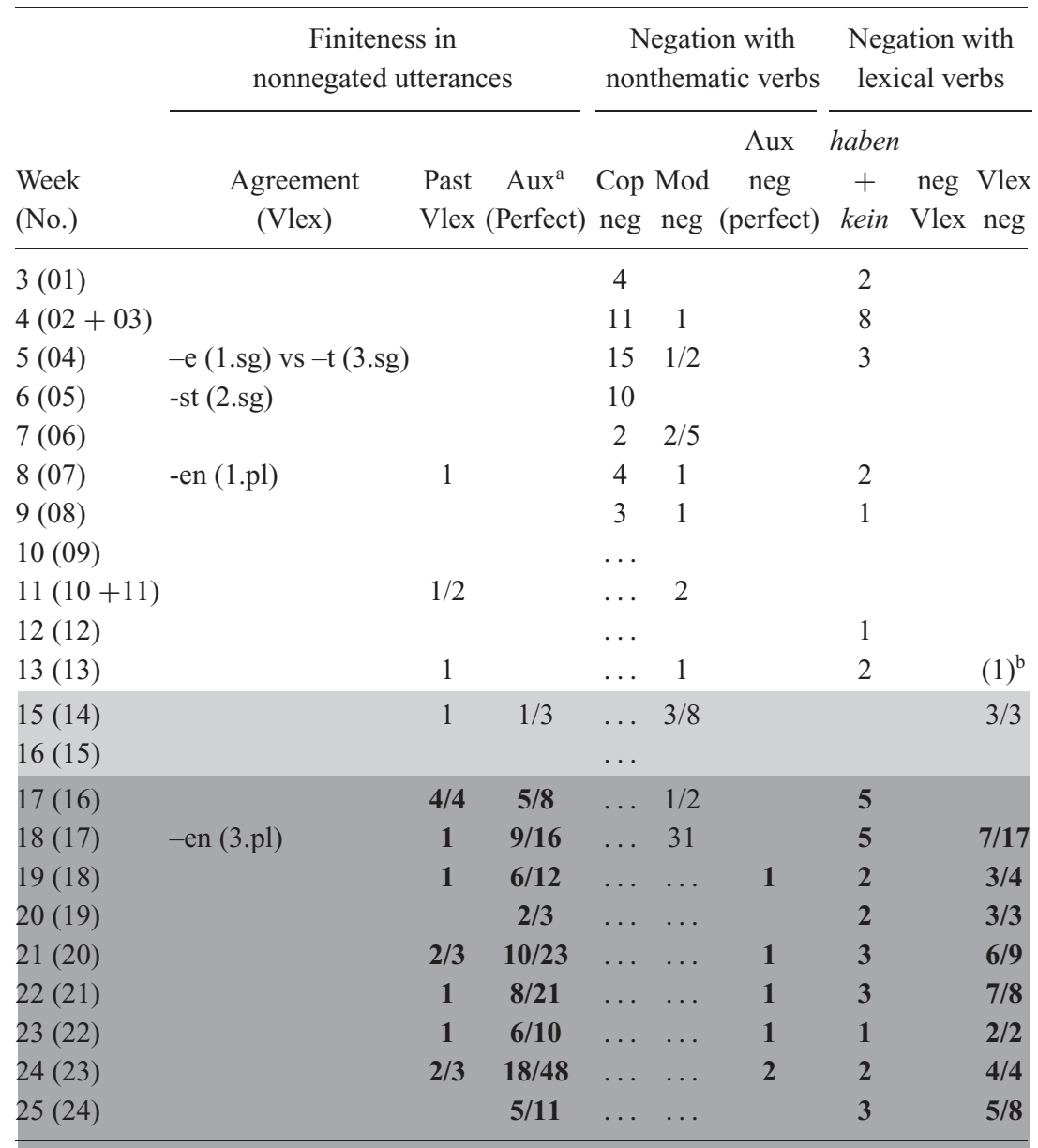

${ }^{a}$ Type indications here refer to occurrences of auxiliaries with different past participles.

${ }^{\mathrm{b}}$ Doubtful occurrence [see example (21)].

Negation is always to the right of modal verbs, too. The structure of modal constructions in negative utterances, however, changes at about the time when the perfect is acquired; that is, from early on, modal verbs are used in combination with negation, but up to week 18 , the cluster modal-negator is never separated $(17 \mathrm{a}-\mathrm{b})$. Thus, it is only after the acquisition of the perfect that we attest cases in which other elements (e.g., pronouns) occur between the modal verb and the negator $(17 \mathrm{c}-\mathrm{d})$. 
(17) Negated modal constructions

a. wir müss nicht sag schön oder toll (D-08)
we must not say fine or great
b. sie kann nicht uns französisch machen (D-14)
she can not us French make
c. er wollt das nicht so machen (D-17)
he wanted this not so make
d. in deutsch jetzt kann ich nicht (D-17)
in German now can I not

Jordens and Dimroth (2006) attest similar structures in L2 Dutch (unanalyzed negative modals of the form kanniet "cannot," magniet "may not," etc.). They presented evidence of a reanalysis of these chunks that takes place after the acquisition of auxiliary verbs. If this is also the case here, it would have to be shown in an in-depth analysis.

As with the other nonthematic verbs, negation is always to the right of finite auxiliaries, too.

(18) Negative placement in perfect constructions

a. in russland wir hat das auch nicht gesprocht über... (D-18)

in Russia we have that also not talked about

b. ich habe das nicht getrinkt (D-20)

I have that not drunk

c. sie hat nicht Titanic gesehen (D-21)

she has not Titanic watched

Thus, we can conclude that the tendency of negated nonthematic verbs to appear in finite form and position, which was observed by Parodi (2000), Giuliano (2003), and Becker (2005) for adult learners, is also applicable for this adolescent learner. We will now turn to the actual test case, namely negation with lexical verbs.

We will compare negative placement with lexical verbs before and after the acquisition of the perfect. There is only one lexical verb that is attested with postverbal negation from the first recording onward. This is the verb haben "have" and it exclusively appears with the cohesive negator kein. This negator appears with no other lexical verb before the acquisition of the perfect: Kein and haben only appear together and form an unproductive early pattern of postverbal negation, in which kein does not agree with the following $\mathrm{NP}^{7}$ 
(19) Examples of the lexical verb haben followed by kein

a. ich habe kein kunst in Russland (D-01)

I have no arts-lesson in Russia

b. und wir hat kein sport (D-02)

and we have-3sg no sports

c. (i) ch habe kein russisch freund hier in Deutschland (D-03)

I have no Russian friend here in

Germany

d. ich habe kein fotos meine vater hier (D-04) I have no photos (of) my father here

It is only from week 18 onward that kein is also attested with other verbs, namely with the copula and in the structure "es gibt kein" (there is no). ${ }^{8}$ Before this, haben + kein are used as an unanalyzed cluster (compare also the targetdeviant occurrences of haben + nicht after this point (23c below); i.e., at a stage where the structure has presumably been analyzed!). We are thus dealing with an unproductive pattern that looks like a lexical verb appearing with postverbal negation but is, in fact, to be taken as an isolated verb with an idiosyncratic pattern of negation.

Before the acquisition of the perfect, the learner makes use of three different types of verb with postverbal negation: cop - nicht, mod - nicht, and habenkein. Through clever use of these three structures, Dascha avoids negation with full lexical verbs. We do not find a single utterance with preverbal negation (remember that these have been massively attested in adult learners). It cannot be excluded that this strategy is influenced by the learner's knowledge of English, where negation of lexical verbs always leads to an analytic construction of a similar type (do-support).

Lexical verbs with postverbal negation become productive only after the acquisition of the perfect and thus in the same order of acquisition that was found for the adult learners. Before weeks 15-17 we only find occurrences of typically rote learned chunks like weiss nicht "don't know," verstehe nicht "don't understand," glaube nicht "don't think." Some other occurrences had to be excluded from the analysis because it is unclear if nicht really has wide scope over VP or is, in fact, meant to express narrow scope on the quantifier viel "many"; see (20a-d). 
(20) Early lexical verbs followed by nicht viel

a. nastja hat nicht so viel hausaufgaben $(D-10)^{9}$ Nastja has not so much homework

b. ich koche nicht viel (D-12)

I cook not much

c. wir haben nicht viel zeit (D-14)

we have not much time

d. sie haben nicht viel interessant (D-14)

they have not much interesting (things)

The first occurrence of the negator nicht following a lexical verb and expressing sentence negation is found in week 13 (i.e., shortly before the perfect is first attested (21).

(21) er willt nicht / eh liebt nicht wann ich fahre diese ski (D-13)

he wants not / eh loves not when I go skiing

This occurrence is with the lexical verb lieben (used here with the meaning of like), but it follows a false start in which nicht is placed to the right of a modal verb. This might have helped the learner to put the lexical verb in the same slot. In Table 5, this occurrence is therefore included in parentheses. In week 15, three lexical verbs with postverbal negation are used.

(22) Lexical verbs with postverbal negation
a. er
guckst nicht wie musee (D-14)
he (=it) looks not like museum
$\mathrm{b}$. in russisch es heisst nicht $\mathrm{x}$ (D-14)
in Russian it be-called not $x$
c. sie wohnt nicht in kleine stadt (D-14)
she lives not in small town

After these utterances in week 15 there is a standstill in the development. It is only in week 18 that lexical verbs with postverbal negation become really frequent and appear with many different lexical verbs.

(23) Examples for productive use of finite lexical verbs with postverbal negation
a. (about the seaside in Russia)
es gibt aber wir wohnt nich (D-17)
it exists but we live not 
b. dann dieses hund kann denken das ich liebe nicht sie (D-17)

than this dog can think that I love

not it

c. besser geht es nicht (D-17)

better goes it not

d. findest nicht schön? (D-17)

find not beautiful?

e. ich habe nicht angst (D-17)

I have not fear

f. sie gucken nicht wie russen (D-17)

they look not like Russians

g. sie schläft nicht für lange lange zeit (D-17)

she sleeps not for (a) long long time

h. da gibt es nicht viel interessante filme (D-17)

there exist not many interesting films

i. zeus macht das nicht (D-18)

zeus does this not

j. er spricht nicht also richtig wie deutscher (D-18)

he talks not in-fact really like German

k. ich kaufe das nicht (D-19)

$I$ buy that not

We can conclude that this adolescent learner differs in many details from the adult learners described earlier. In addition to the early acquisition of subjectverb agreement, the greatest difference clearly lies in the complete avoidance of Neg-V structures. With respect to acquisition orders, however, we find no difference. Like adult learners, this adolescent learner goes from (I) no finiteness to (II) finiteness with light verbs and auxiliaries and only then acquires (III) finiteness with lexical verbs (as indicated through postverbal negation).

We will now analyze the data for the child learner in a parallel fashion to see if these orders hold for her.

\section{Acquisition of Negation and Finiteness in the Child Learner Nastja}

As mentioned earlier, some of the early recordings of Nastja are less informative than those of Dascha. In particular, the recordings made in weeks 4 and 5 contain only a small number of more complete learner utterances, which considerably 
reduces the number of interpretable occurrences of the structures of interest. However, as will be seen later, this does not affect the argument. As with the adolescent learner, we will first address finiteness in nonnegated utterances and in negated utterances, respectively.

\section{Finiteness in Nonnegated Utterances}

Nastja acquires the different verb types in the same order as her older sister Dascha. Lexical verbs and the copula appear from the first week of residence onward. Modal verbs are added in week 6. The perfect appears in week 11, a few weeks earlier than in the older learner Dascha. Once the construction is acquired, it becomes immediately quite productive and frequent. Table 6 shows the order of acquisition of different verb types for the child learner Nastja.

Table 6 Order of acquisition of different verb types in the child learner Nastja

\begin{tabular}{lcccc}
\hline Weeks (No.) & Vlex & Cop $^{1}$ & Mod & Aux ${ }^{\mathrm{b}}$ (perfect) \\
\hline $3(01)$ & $13 / 22$ & 33 & & \\
$4(02+03)$ & $3 / 6$ & 26 & & \\
$5(04)$ & $3 / 4$ & 3 & & \\
$6(05)$ & $6 / 23$ & 6 & $3 / 4$ & \\
$7(06)$ & $3 / 6$ & 8 & & \\
$8(07)$ & $20 / 40$ & 21 & $5 / 5$ & \\
$9(08)$ & $13 / 72$ & $\ldots$ & $5 / 6$ & \\
$10(09)$ & $\ldots$ & $\ldots$ & $3 / 6$ & \\
$11(10)$ & $\ldots$ & $\ldots$ & $4 / 4$ & $6 / 11$ \\
$12(11)$ & $\ldots$ & $\ldots$ & $4 / 7$ & $4 / 9$ \\
$13(12)$ & $\ldots$ & $\ldots$ & $8 / 10$ & $2 / 2$ \\
$15(13)$ & $\ldots$ & $\ldots$ & $\ldots$ & $5 / 14$ \\
$16(14)$ & $\ldots$ & $\ldots$ & $\ldots$ & $7 / 8$ \\
$17(15)$ & $\ldots$ & $\ldots$ & $\ldots$ & $10 / 17$ \\
$18(16)$ & $\ldots$ & $\ldots$ & $\ldots$ & $7 / 11$ \\
$19(17)$ & $\ldots$ & $\ldots$ & $\ldots$ & $33 / 59$ \\
$20(18)$ & $\ldots$ & $\ldots$ & $\ldots$ & $\ldots$ \\
$21(19)$ & $\ldots$ & $\ldots$ & $\ldots$ & $\ldots$ \\
$22(20)$ & $\ldots$ & $\ldots$ & $\ldots$ & $\ldots$ \\
$23(21)$ & $\ldots$ & $\ldots$ & $\ldots$ & \\
$24(22)$ & $\ldots$ & $\ldots$ & $\ldots$ & \\
$25(23)$ & $\ldots$ & $\ldots$ & $\ldots$ & \\
\hline A11 & $\ldots$ & $\ldots$ & $\ldots$ & \\
\hline
\end{tabular}

${ }^{a}$ All forms of the copula were counted as one (lexical) type.

${ }^{\mathrm{b}}$ To make sure that the learner does not only use fixed collocations, type indications here refer to occurrences of auxiliaries with different past participles. 
Up to week 9, the copula predominantly appears in the pattern das ist $x$ "this is x." There are only a few copula constructions containing personal pronouns [see (24b)]. The copula starts to show correct person-number marking in contexts other than the third person singular in (07).

(24) Early occurrences of the copula

$\begin{array}{ll}\text { a. das } & \text { ist zwei jüngen (N-01) } \\ \text { this } & \text { is two boys } \\ \text { b. er } & \text { ist dumm (N-05) } \\ \text { he } & \text { is stupid } \\ \text { c. äpfel } & \text { sind klein (N-07) } \\ \text { apples } & \text { are small } \\ \text { d. ich } & \text { bin in die musikschule (N-08) } \\ \text { I } & \text { am in the music school }\end{array}$

Nastja, like her older sister, initially produces utterances with an SVO structure. As with Dascha, modal verbs and infinitives are first treated as a cluster and only later separated:

(25) Early utterances with modal and lexical verb

a. meine musiklehrerin

kann sprechen russisch $(\mathrm{N}-05)$

$\begin{array}{ll}\text { my music teacher can speak Russian } \\ \text { b. Marco } & \text { willt sitzen mit mir (N-05) } \\ \text { Marco } & \text { wants sit with me } \\ \text { c. ich } & \text { kann mit er spielen } \\ \text { und ich } & \text { kann er füttern (N-07) } \\ \text { I } & \text { can with him play } \\ \text { and } I & \text { can he feed }\end{array}$

Here are the earliest occurrences of the perfect. Up to recording (13), only forms of haben "have" are used as auxiliaries. In recordings (12) and (13), Nastja mainly uses the form hatte "had" instead of hat/habe [see (26c-e)]. There does not seem to be any meaning contrast. Forms of haben also appear in contexts where the target language chooses the auxiliary sein [see (26f)]. From (13) onward, sein is used as an auxiliary, but it is restricted to a small number of lexical verbs [see $(26 \mathrm{~g}-\mathrm{i})$ ].

(26) First occurrences of the perfect
a. ich habe gesehen diese batterie (N-11)
I have seen this battery 


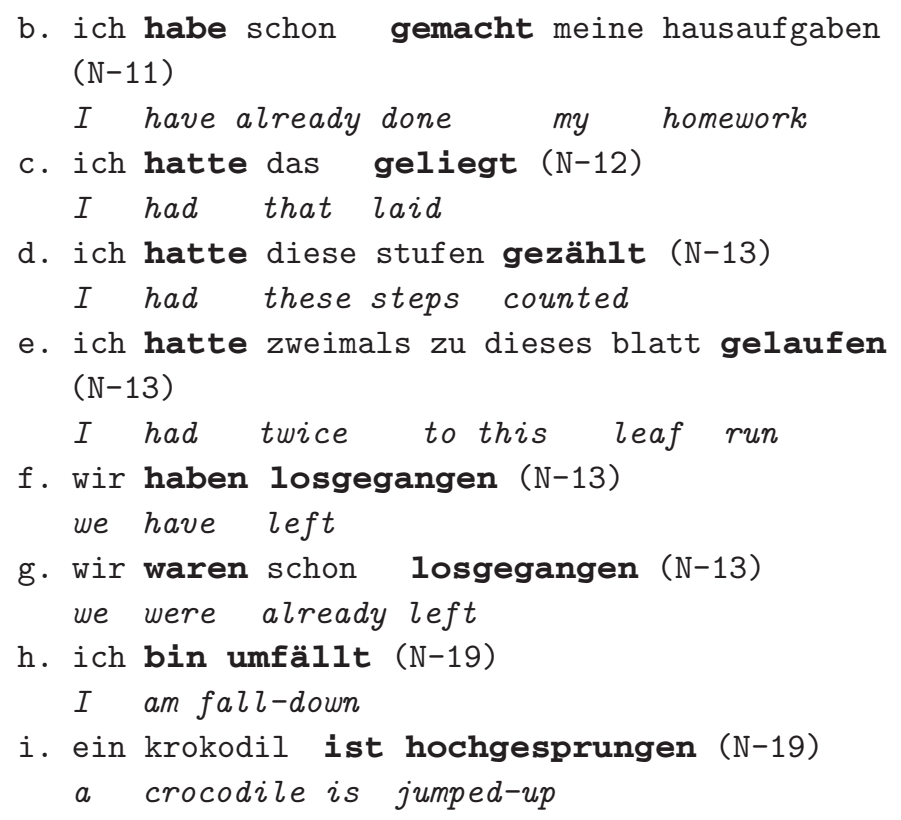

Let us now turn to an analysis of inflectional marking (subject-verb agreement and tense) on lexical and nonthematic verbs. Table 7 shows the development of these properties over time. A column with the first occurrences of the perfect (from Table 6) is added and the rows displaying the data from the relevant weeks are shaded for ease of comparison.

Nastja begins to work on subject-verb agreement from early on. In the third recording (i.e., in her fourth week of contact with the target language), she already distinguishes between the $-e$ suffix used for the first person singular and the $-t$ suffix used for the third person singular (27a). Self-corrections like in (27b) indicate early sensitivity for contrasting verbal inflections. Up to week 6 , the contrast between $-e$ and $-t$ forms is further established. Both markings occur with a few new verbs and there are only very few overextensions, especially of the suffix $-t$ as in utterance $(27 \mathrm{c})$ which is in fact referring to the past. Additional evidence for the productivity of this system comes from overgeneralizations of the $-t$ morpheme on modal verbs [see (27d)], which do not mark third person singular with $-t$ in the target language.

(27) Early inflections for first and third person singular

a. ich male haus und Kimberly malt haus (N-01)

I draw-1sg house and $K . \quad$ draw-3sg house 
Table 7 Acquisition of verbal inflections in the child learner Nastja

\begin{tabular}{|c|c|c|c|c|c|}
\hline \multirow[b]{2}{*}{ Weeks (No.) } & \multirow{2}{*}{$\begin{array}{c}\text { Subj--verb } \\
\text { agreement (Vlex) }\end{array}$} & \multicolumn{3}{|c|}{ Past tense } & \multirow{2}{*}{$\begin{array}{c}\text { Aux }^{\mathrm{a}} \\
\text { (perfect) }\end{array}$} \\
\hline & & Cop & Mod & Vlex & \\
\hline \multicolumn{6}{|l|}{$3(01)$} \\
\hline $4(02+03)$ & $-\mathrm{e}(1 . \mathrm{sg}) \mathrm{vs}-\mathrm{t}(3 . \mathrm{sg})$ & & & & \\
\hline \multicolumn{6}{|c|}{$5(04)$} \\
\hline $6(05)$ & $-\mathrm{st}(2 . \mathrm{sg})$ & $1 / 3$ & & & \\
\hline \multicolumn{6}{|l|}{$7(06)$} \\
\hline $8(07)$ & -en (1.pl) & $1 / 2$ & & & \\
\hline $9(08)$ & & $2 / 4$ & & & \\
\hline $10(09)$ & & $1 / 4$ & & 1 & \\
\hline $11(10)$ & & $2 / 22$ & & & 1 \\
\hline $12(11)$ & & 2/9 & & & $6 / 11$ \\
\hline $13(12)$ & & $1 / 12$ & $2 / 3$ & & $4 / 9$ \\
\hline $15(13)$ & -en (3.pl) & 2/52 & $2 / 7$ & & $15 / 31$ \\
\hline $16(14)$ & & & & $2 / 4$ & $2 / 2$ \\
\hline $17(15)$ & & $1 / 8$ & & $1 / 2$ & $5 / 14$ \\
\hline $18(16)$ & & $1 / 3$ & 1 & 1 & $7 / 8$ \\
\hline $19(17)$ & & $2 / 9$ & $1 / 3$ & $3 / 3$ & $10 / 17$ \\
\hline $20(18)$ & & 2/14 & 1 & $1 / 3$ & 7/11 \\
\hline $21(19)$ & & 2/92 & 3/10 & $1 / 2$ & $33 / 59$ \\
\hline $22(20)$ & & $\ldots$ & 1 & $2 / 2$ & $\ldots$ \\
\hline $23(21)$ & & $\cdots$ & 1 & & $\ldots$ \\
\hline $24(22)$ & & $\ldots$ & $2 / 11$ & $3 / 3$ & $\ldots$ \\
\hline $25(23)$ & & $\ldots$ & $3 / 10$ & 9/12 & ... \\
\hline
\end{tabular}

${ }^{a}$ Type indications here refer to occurrences of auxiliaries with different past participles.

b. er kamm / kammst / er kammt...(N-01)

he comb-stem / comb-2sg / he comb-3sg

c. ich gehe mit meine klasse schwimmen.

I go-1sg with my class swimming

aber heute ich geht nicht (N-05)

but today I go-3sg not

d. Marco willt sitzen mit mir und Pascal willt sitzen mit mir (N-05)

M. wants sit with me and $P$. wants sit with me. 
In the sixth week, the -st suffix is added, marking the second person singular. It first occurs in questions only and becomes fused with the pronoun that follows due to inversion.

(28) First occurrences of -st

a. has ( $t)$ du tamagochi? (N-05) have-2sg you tamagochi?

b. liebs $(t)$ du schwimmen? (N-05) love-2sg you swimming?

From week 8 onward, the suffix $-e n$ starts to be used systematically. It is first productively used in first person plural contexts [see (29a-b)]. Third plural contexts remain quite rare and nontarget adequate suffixes are used as well (29c).

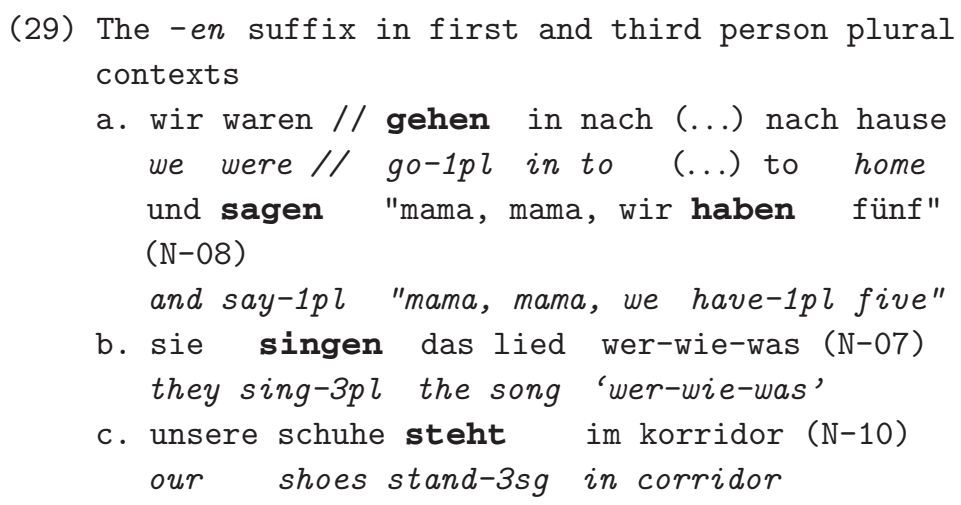

Similar to the older learner, past tense is first marked on the copula (sixth week). Modal verbs and lexical verbs develop a little later. From week 16 onward, the past tense of modal and lexical verbs is used productively and with higher type and token frequency than by Dascha. Agreement of lexical verbs is acquired gradually, but the acquisition criteria adopted from L1 studies (Bittner, 2003) are reached as early as for Dascha. Here are the first occurrences of copula, modal verbs, and lexical verbs (including irregular verbs with overextended regular past tense inflections) with morphological past tense marking.

(30) First past tense markings with different verb types

a. ich war geht $(\mathrm{N}-05)$

I was go

b. wir waren in Russland ( $\mathrm{N}-08)$

we were in Russia 


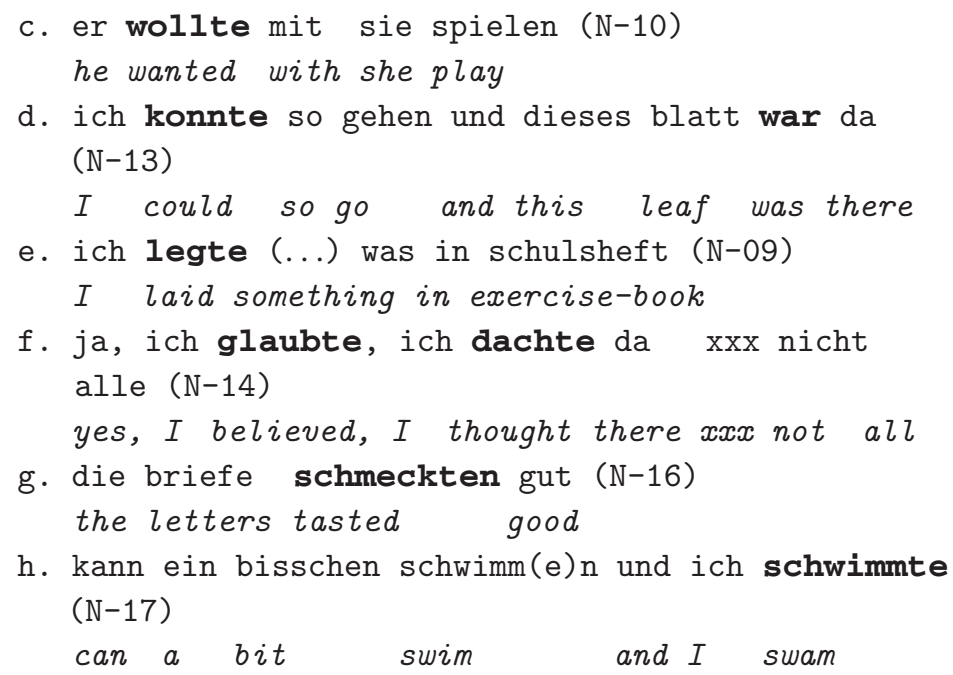

Both learners acquire finiteness-related properties in nonnegated utterances in a very similar way. Orders of acquisition are equal, but there is a difference in rate for the acquisition of the past tense and auxiliaries. The child learner Nastja acquires both properties a few weeks earlier than the older learner (after 10-11 instead of 15-17 weeks). Otherwise, the developmental pattern looks very similar.

\section{Negation Before and After the Acquisition of the Perfect}

As with Dascha, we will now compare negative placement with different types of verb before and after the acquisition of the perfect and see if the acquisition order found in the adult and adolescent data (no postverbal negation before the acquisition of the perfect) is also attested for this child. The development of negative placement with different verb types is summarized in Table 8. As indicated by the gray area, the use of postverbal negation with finite verbs precedes the productive use of the perfect by several weeks. We will now illustrate the development of negation with nonthematic and lexical verbs, starting with nonthematic verbs.

Unlike Dascha, Nastja does not omit the copula in negative utterances. The negator is in postfinite position. From week 11 onward there are also a few constructions with kein $(31 \mathrm{c}-\mathrm{d})$.

(31) Negative utterances containing a copula

a. K. ist nicht jetzt meine freundin (N-01)

$K$. is not now my friend 
Table 8 Negative placement in relation to the acquisition of the perfect in the child learner Nastja

\begin{tabular}{|c|c|c|c|c|c|c|c|c|c|}
\hline \multirow[b]{2}{*}{ Weeks (No.) } & \multicolumn{3}{|c|}{$\begin{array}{c}\text { Finiteness in } \\
\text { nonnegated utterances }\end{array}$} & \multicolumn{3}{|c|}{$\begin{array}{c}\text { Negation with } \\
\text { nonthematic verbs }\end{array}$} & \multicolumn{3}{|c|}{$\begin{array}{l}\text { Negation with } \\
\text { lexical verbs }\end{array}$} \\
\hline & $\begin{array}{l}\text { Agreement } \\
\text { Vlex }\end{array}$ & $\begin{array}{l}\text { Past } \\
\text { Vlex }\end{array}$ & $\begin{array}{c}\text { Aux }^{\mathrm{a}} \\
(\text { Perfect) }\end{array}$ & $\begin{array}{l}\text { Cop } \\
\text { neg }\end{array}$ & $\begin{array}{c}\text { Mod } \\
\text { neg }\end{array}$ & $\begin{array}{c}\text { Aux } \\
\text { neg } \\
\text { (Perfect) }\end{array}$ & $\begin{array}{c}\text { haben } \\
+ \\
\text { kein }\end{array}$ & $\begin{array}{l}\text { neg } \\
\text { Vlex }\end{array}$ & $\begin{array}{l}\text { Vlex } \\
\text { neg }\end{array}$ \\
\hline $3(01)$ & & & & 2 & & & & & \\
\hline $4(02+03)$ & $\begin{array}{l}-\mathrm{e}(1 . \mathrm{sg}) \mathrm{vs} \\
-\mathrm{t}(3 . \mathrm{sg})\end{array}$ & & 4 & & & & & 1 & \\
\hline $5(04)$ & & & & & & & & & \\
\hline $6(05)$ & - st (2.sg) & & & & & & & 1 & $2 / 6$ \\
\hline $7(06)$ & & & & & & & & & $1 / 2$ \\
\hline $8(07)$ & -en (1.pl) & & & 1 & 1 & & & 1 & $7 / 10$ \\
\hline $9(08)$ & & & & $\ldots$ & $2 / 6$ & & & 1 & $2 / 12$ \\
\hline $10(09)$ & & 1 & & 4 & $2 / 5$ & & & & $3 / 4$ \\
\hline $11(10)$ & & & 1 & $\ldots$ & $2 / 2$ & & & & $2 / 3$ \\
\hline $12(11)$ & & & $6 / 11$ & $\ldots$ & $2 / 5$ & & & & $2 / 5$ \\
\hline $13(12)$ & & & $4 / 9$ & $\ldots$ & $1 / 16$ & & & & $4 / 10$ \\
\hline $15(13)$ & -en (3.pl) & & $15 / 31$ & $\ldots$ & $2 / 4$ & 5 & & & $4 / 9$ \\
\hline $16(14)$ & & $2 / 4$ & $2 / 2$ & $\ldots$ & & & & & $2 / 3$ \\
\hline $17(15)$ & & $1 / 2$ & $5 / 14$ & $\ldots$ & $4 / 11$ & 2 & & & $6 / 8$ \\
\hline $18(16)$ & & 1 & $7 / 8$ & $\ldots$ & $\ldots$ & 3 & & & $4 / 6$ \\
\hline $19(17)$ & & $3 / 3$ & $10 / 17$ & $\ldots$ & $\ldots$ & 3 & & & $7 / 28$ \\
\hline $20(18)$ & & $1 / 3$ & $7 / 11$ & $\ldots$ & $\ldots$ & 2 & & & $3 / 3$ \\
\hline $21(19)$ & & $1 / 2$ & $33 / 59$ & $\ldots$ & $\ldots$ & 9 & & & $9 / 12$ \\
\hline $22(20)$ & & $2 / 2$ & $\ldots$ & $\ldots$ & $\ldots$ & 2 & & & $4 / 6$ \\
\hline $23(21)$ & & & $\ldots$ & $\ldots$ & $\ldots$ & 5 & & & $5 / 5$ \\
\hline $24(22)$ & & $3 / 3$ & $\ldots$ & $\ldots$ & $\ldots$ & 7 & & & $8 / 9$ \\
\hline $25(23)$ & & $9 / 12$ & $\ldots$ & $\ldots$ & $\ldots$ & 6 & & & $8 / 13$ \\
\hline
\end{tabular}

${ }^{a}$ Type indications here refer to occurrences of auxiliaries with different past participles.

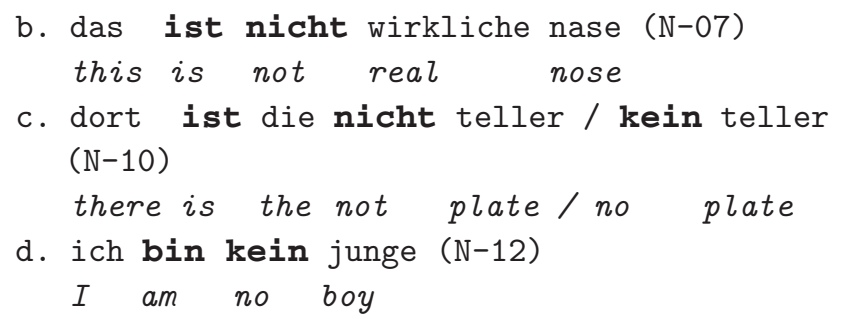


As observed for Dascha, negation appears immediately after modal verbs. Again, a separation of the modal-negation cluster is only achieved after the acquisition of the perfect (weeks 11 and 12). The following modals are attested in negative utterances: darf nicht (week 8), will nicht, kann nicht (week 9), and soll nicht, muss nicht (week 17). The first occurrences of a structure with other elements intervening between modal and negator are found in week 12:

(32) Negative utterances with modal verbs and an intervening pronoun

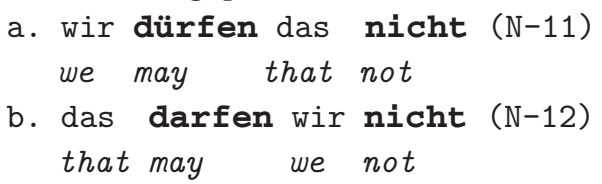

Here are the first occurrences of the perfect with negation. As with the other nonthematic verbs, negation is always postfinite:

(33) Negative placement in perfect constructions

a. ich hatte das nicht geweisst (N-13)
I had that not known
b. wir haben noch nicht aufnahmen gemacht (N-16)
we have yet not recordings made
c. ich habe nicht ganz fest gesitzt (N-19)
I have not really tightly sat

Overall, the postfinite position of negation with nonthematic verbs confirms the pattern found in adults and the adolescent learner. We will now turn to negation with lexical verbs and see how this develops before and after the acquisition of nonmodal auxiliaries (the perfect).

In Nastja's data, there is no trace of an unproductive pattern of the type haben + kein that was found in Dascha. Instead, we observe altogether four early structures with preverbal negation that were absent from Dascha's data. ${ }^{10}$ In the first two of these utterances (34a-b), preverbal negation might be due to the fact that the negator has narrow scope over the lexical verb. This is not the case in the other two utterances with morphologically nonfinite verbs [e.g., $(34 c-d)]$. These occurrences are the only ones in the entire corpus of both learners that have the structure, which is so massively attested in adult data. ${ }^{11}$

(34) Preverbal negation with lexical verbs

a. (why can you play with your tamagochi during the breaks?)

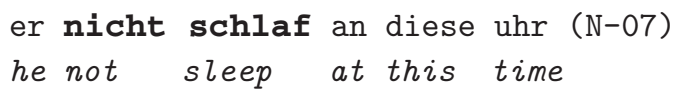


b. Dascha hat latein, aber Dascha nicht liebt latein ( $\mathrm{N}-08$ )

Dascha has Latin, but Dascha not loves Latin

c. er nicht kauf steine (N-02)

he not buy stones

d. ich sehe, er nicht gehen (N-05)

I see, he not go

Unlike adult learners and her adolescent sister Dascha however, Nastja produces lexical verbs with postverbal negation from the earliest recording on. The very first occurrence (35) is doubtful, however, and had to be excluded from further analysis. Its structure differs from the pattern used at that early stage, in which the lexical verb and negation always occur adjacent to each other see examples in (36) below], and it is therefore unclear whether the learner wants to express sentence negation or narrow scope negation.

(35) ich sehe diese bilder nichts exkursion (N-01)

I see these pictures not excursion

Postverbal negation with lexical verbs is clearly productive from the sixth week onward. It is unclear if the low numbers before are due to the relatively small amount of data available from some of the previous recordings. The following list contains postverbal negation with lexical verbs ${ }^{12}$ that appear before auxiliaries are productively used in perfect constructions from recording 11 (i.e., week 12) onward.

(36) Postverbal negation with lexical verbs appearing earlier than the perfect
a. heute ich geht nicht (N-05) today I go not
b. A. auch geht nicht mit für schwimmen (N-05)
A. also goes not with to swimming
c. ich habe nicht diese (N-05)
I have not those
d. ich habe nicht schlüssel (N-05)
I have not keys
e. dascha hat nicht schlüssel (N-05)
D. has not keys
f. ich habe nicht musik (N-05)
I have not music
g. ich tanze nicht (N-07)
I dance not 


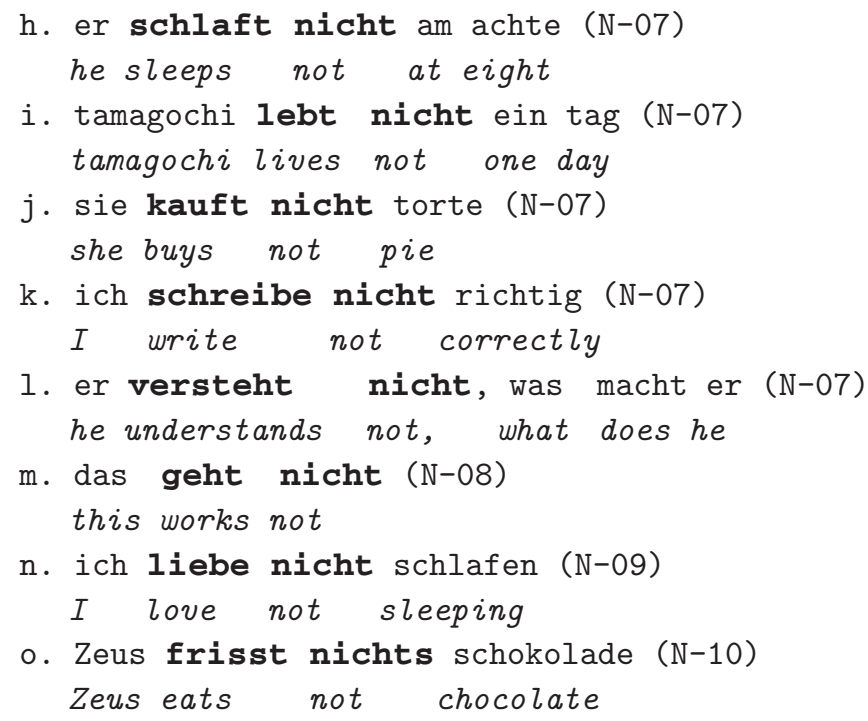

From the fourth week onward there are also constructions with postverbal kein. This negator occurs mostly with haben but also with some different lexical verbs. Additionally, as shown in (36c-f), haben does not exclusively appear with kein, but also with nicht.

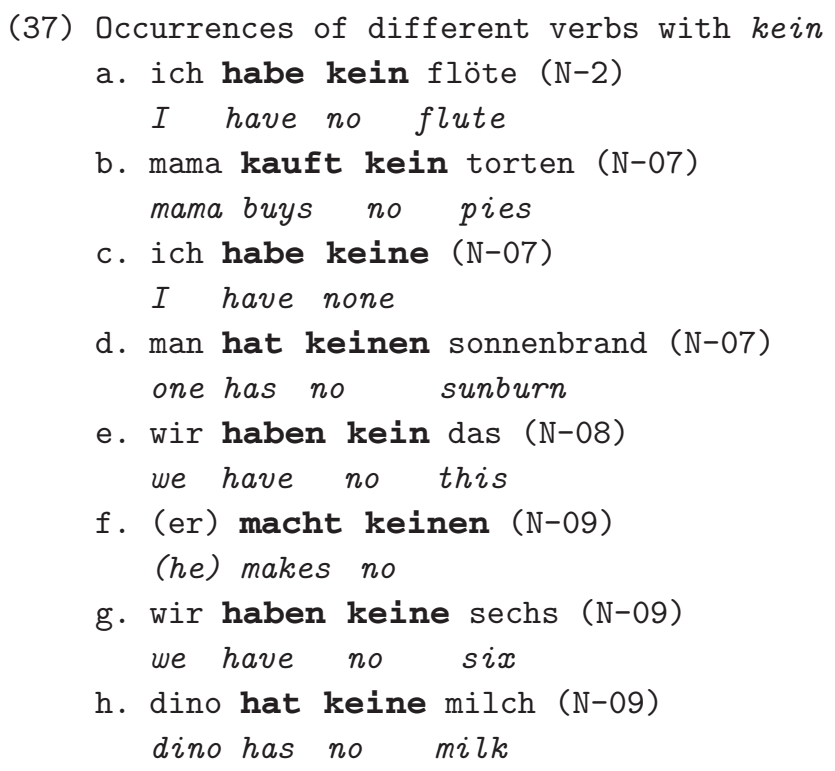


i. pinguin hat kein fleisch und milch, er hat fisch $(\mathrm{N}-07)$ penguin has no meat and milk, he has fish

In sum, Nastja's data first show a stage (before week 8) in which preverbal and postverbal negation with lexical verbs co-occur. Note, however, that type and token frequency are higher for postverbal negation. After week 8, lexical verbs are consistently negated postverbally and can thus be considered to be in a syntactically finite position before the first auxiliaries (perfect) appear. The order of acquisition for this child learner differs from that of adults and the adolescent learner.

\section{Summary and Discussion}

For this study, learners of different ages were compared with respect to the order in which they acquired different properties of negation and finiteness. Based on a literature review, the following three stages were distinguished for adult learners.

I. negation without finiteness in topic-predicate structures;

II. postverbal negation with finite auxiliary-verbs (perfect);

III. postverbal negation with finite lexical verbs.

The acquisition data from the adolescent learner analyzed in the present article show both similarities and differences vis-à-vis the adult order of acquisition. Subject-verb agreement starts to develop much earlier than in the adult learners, but raising of lexical verbs over negation only appears after the acquisition of the perfect (no "Vlex-nicht" before the acquisition of auxiliaries and the morphological coding of tense contrasts). Before this turning point, the learner avoids ungrammatical neg-V structures through the use of three targetlike patterns: cop-nicht, mod-nicht, and haben-kein (have-no). Due to this strategy that might be influenced by her prior knowledge of English, the adolescent's production sounds less deviant than that found in adults, but it follows the same acquisitional sequence in that analytical constructions with a separate item (nonthematic verb) as the carrier of finiteness (Stage II) are achieved before a synthetic marking with finite lexical verbs in a finite position (Stage III).

The child learner resembles the adolescent learner in that subject-verb agreement is acquired before any other property of finiteness. There are only two clear occurrences of preverbal negation in the child learner's data. The turning point at which other important components of finiteness (auxiliaries and tense marking) 
become productive is reached even earlier than in the adolescent learner. Importantly though, the child learner is not only faster overall but also shows a difference in order of acquisition. A core property of finiteness, namely verb raising of lexical verbs over negation, is acquired before the auxiliary system is in place: Stage III seems to be reached before stage II. This is a clear difference in order of acquisition.

Can we draw general conclusions with respect to the age factor? Careful longitudinal documentations on the SLA of untutored children and especially studies comparing learners who differ in age but not in input conditions are still quite rare, and the present study has only two subjects. Therefore, we are not yet in a position to decide in a general way, whether "child L2 acquisition is like adult L2 acquisition and both are distinct from child L1 acquisition" or "child L2 acquisition is like child L1 acquisition and both are distinct from adult L2 acquisition," as discussed in Schwartz (2003, p. 27ff).

The data presented in this article speak against the view that child L2 acquisition is like adult L2 acquisition, because a different course of development was found for the child and adolescent/adult learners in terms of the order of acquisition of core elements of grammar. ${ }^{13}$ The child L2 learner was shown to develop finiteness marking with all types of verb in parallel and to be less dependent than the older learners on a stepwise path to the target system traversing intermediate analytic constructions. If this can be confirmed (e.g., by investigating orders of acquisition among more untutored L2 learners at different ages), the conclusion would have to be that child L2 learners differ from older learners not only in rate and typical end state but also in the acquisition process itself. In the domain of negation and finiteness, the adult strategy is in fact a very conservative one: When integrating new structural properties, learners tend to leave the organizational principles of their earlier learner variety intact as long as possible and attempt to proceed in a way that allows them to tackle one property of finiteness at a time. In contrast, the capacity to drop an existing organization with ease, to adopt targetlike patterns immediately without going through analytical steps, and to work on several phenomena at a time might be more typical for children. Of course, more longitudinal studies are needed in order to shed light on differences in the way learners approach the task of SLA. The differences among child, adolescent, and adult learners that were found here suggest that the study of the process, and not only of the end product, of language acquisition can inform the age factor discussion. 


\section{Notes}

1 For a discussion of the relation between sentence negation and constituent negation, see Moser (1992). Studies including the L2 acquisition of other types of negation (e.g., anaphoric and replacing negation) are Becker (2005), Bernini (2000), Dietrich and Grommes (1998), and Silberstein (2001), among others.

2 See, for example, Cancino, Rosansky, and Schumann (1978) for an early study on the untutored acquisition of negation in English.

3 For an overview on similarities and differences between these learners in an array of morphosyntactic domains, see Dimroth (2007).

4 Compare similar findings in Haberzettl (2005) for L2 acquisition of German by Russian children.

5 See also Dimroth and Haberzettl (in press).

6 English words are marked with @e; Russian words are marked with@r.

7 In haben-contexts, kein can also be found without a verb, somehow alternating with haben as if it could carry the meaning of "have-not" alone. Compare (D-01): in russland wir habe kantin ("in Russia we have canteen") to (D-01): in deutschland keine kantin ("in Germany no canteen").

8 There is only one occurrence of a lexical verb with kein (ich spielt kein geige (D-20) "I played no violin").

9 This is at the same time the first occurrence of haben with nicht.

10 It is indeed possible that this difference between the two learners is due to Dascha's prior knowledge of English.

11 Interestingly, long after postverbal negation with lexical verbs has been acquired, there is one occurrence of preverbal negation with a morphologically finite verb. Nastja is looking at a person on a diving board and asking herself: springt, nicht springt, springt, nicht springt? "jumps, not jumps, jumps, not jumps” (N-23).

12 Again, early, probably rote-learned chunks like ich weiss nicht, ich kenne nicht "I don't know," ich verstehe nicht "I don't understand," ich glaube nicht "I don'”t think" have been excluded.

13 Even though this was not in the focus of interest, the results also speak against the view that child L2 acquisition is like child L1 acquisition, because there clearly is some L1 influence (e.g., on basic word order) in the child L2 case.

\section{References}

Bast, C. (2003). Der Altersfaktor im Zweitspracherwerb. Die Entwicklung der grammatischen Kategorien Numerus, Genus und Kasus in der Nominalphrase im ungesteuerten Zweitspracherwerb des Deutschen bei russischen Lernerinnen. Doctoral dissertation, Universität zu Köln, Köln. Retrieved January 1, 2005, from http://kups.ub.uni-koeln.de/frontdoor.php?source_opus=936. 
Becker, A. (2005). The semantic knowledge base for the acquisition of negation and the acquisition of finiteness. In H. Hendriks (Ed.), The structure of learner varieties (pp. 263-314). Berlin: Mouton de Gruyter.

Bernini, G. (2000). Negative items and negation strategies in non-native Italian. Studies in Second Language Acquisition, 22, 399-438.

Birdsong, D. (2004). Second language acquisition and ultimate attainment. In A. Davies \& C. Elder (Eds.), Handbook of applied linguistics (pp. 82-105). Oxford: Blackwell.

Bittner, D. (2003). The emergence of verb inflection in two German-speaking children. In D. Bittner, W. U. Dressler, \& M. Kilani-Schoch (Eds.), Development of verb inflection in first language acquisition. A cross-linguistic perspective (pp. 53-87). Berlin: de Gruyter.

Bongaerts, T. (1999). Ultimate attainment in foreign language pronunciation: The case of very advanced late foreign language learners. In D. Birdsong (Ed.), Second language acquisition and the critical period hypothesis (pp. 133-159). Mahwah, NJ: Erlbaum.

Butler, K., \& Hakuta, Y. (2004). Bilingualism and Second language acquisition. In T. K. Bhatia, \& W. Ritchie (Eds.), The handbook of bilingualism (pp. 114-145). Oxford: Blackwell.

Cancino, H., Rosansky, E., \& Schumann, J. (1978). The acquisition of English negatives and interrogatives by native Spanish speakers. In E. Hatch (Ed.), Second language acquisition: A book of readings (pp. 207-230). Rowley, MA: Newbury House.

DeKeyser, R. M., \& Larson-Hall, J. (2005). What does the critical period really mean? In J. F. Kroll \& A.M.B. de Groot (Eds.), Handbook of bilingualism: Psycholinguistic approaches (pp. 89-108). Oxford: Oxford University Press.

Dietrich, R., \& Grommes, P. (1998). 'nicht'. Reflexe seiner Bedeutung und Syntax im Zweitspracherwerb. In H. Wegener (Ed.), Eine zweite Sprache lernen. Empirische Untersuchungen zum Zweitspracherwerb (pp. 173-202). Tübingen: Narr.

Dimroth, C. (2007). Zweitspracherwerb bei Kindern und Jugendlichen: Gemeinsamkeiten und Unterschiede. In T. Anstatt (Ed.), Mehrsprachigkeit bei Kindern und Erwachsenen (pp. 115-138). Tübingen: Narr-Francke.

Dimroth, C., \& Haberzettl, S. (in press). More is more: Language acquisition in children. In S. Haberzettl (Ed.), The age factor and the state of language acquisition. Berlin/New York: De Gruyter.

Giuliano, P. (2003). Negation and relational predicates in French and English as second languages. In C. Dimroth \& M. Starren (Eds.), Information structure and the dynamics of language acquisition (pp. 119-158). Amsterdam: Benjamins.

Haberzettl, S. (2005). Der Erwerb der Verbstellungsregeln in der Zweitsprache Deutsch durch Kinder mit russischer und türkischer Muttersprache. Tübingen: Niemeyer. 
Hyltenstam, K., \& Abrahamson, N. (2003). Maturational constraints in SLA. In C. J. Doughty \& M. Long (Eds.), The handbook of second language acquisition (pp. 539-588). Oxford: Blackwell.

Jordens, P., \& Dimroth, C. (2006). Finiteness in children and adults learning Dutch. In D. Bittner \& N. Gagarina (Eds.), Acquisition of verb grammar and verb arguments (pp. 173-200). Dordrecht: Kluwer.

Klein, W. (2006). On finiteness. In V. van Geenhoven (Ed.), Semantics in acquisition. Dordrecht: Springer (pp. 245-272).

MacWhinney, B. (2000). The CHILDES project: Tools for analyzing talk (3rd ed.). Mahwah, NJ: Erlbaum.

Meisel, J. M. (1997). The acquisition of the syntax of negation in French and German. Contrasting first and second language development. Second Language Research, 13, $227-263$.

Moser, M. G. (1992). The negation relation: Semantic and pragmatic aspects of relational analysis of sentential negation. Unpublished doctoral thesis, University of Pennsylvania, Philadelphia.

Parodi, T. (2000). Finiteness and verb placement in second language acquisition. Second Language Research, 16, 355-381.

Schwartz, B. D. (2003). Child L2 acquisition: Paving the way. Proceedings of BUCLD 27, B. Beachley, A. Brown, \& F. Conlin (Eds.), (pp. 26-50). Somerville, MA: Cascadilla Press.

Silberstein, D. (2001). Facteurs interlingues et spécifiques dans l'acquisition non-guidée de la négation en anglais L2. Acquisition et interaction en langue etrangère, 14, 25-58.

Singleton, D., \& Ryan, L. (2004). Language acquisition: The age factor. Clevedon, UK: Multilingual Matters.

Van Boxtel, S., Bongaerts, T., \& Coppen, P. A. (2003). Native-like attainment in L2 syntax. In S. Foster-Cohen \& S. Pekarekdr Doehler (Eds.), EUROSLA yearbook (Vol. 3, pp. 157-181). Amsterdam: Benjamins. 